Jurnal Abdidas Volume 2 Nomor 6 Tahun 2021 Halaman 1276 - 1280

JURNAL ABDIDAS

http://abdidas.org/index.php/abdidas

\title{
Sosialisasi tentang Bahaya Penyalagunaan Narkoba di Kalangan Masyarakat Desa Bualemo
}

\author{
Nur Moh. Kasim ${ }^{1}$, Sri Nanang Meiske Kamba ${ }^{2 凶}$, Trubus Semiaji ${ }^{3}$ \\ Universitas Negeri Gorontalo, Indonesia ${ }^{1,2,3}$ \\ E-mail : nurkasim76@yahoo.co.id ${ }^{1}$, meiskekamba@gmail.com $^{2}$, trubussemiaji@ung.ac.id $^{3}$
}

\begin{abstract}
Abstrak
Penyalahgunaan narkoba di Indonesia semakin meningkat dan persoalan yang ditimbulkan juga semakin kompleks. Penyalagunaan narkoba tidak dipungkiri banyak terjadi dikalangan remaja yang berdampak buruk baik secara fisik, psikis, ekonomi sosial dan lain sebagainya. Perilaku sebagian remaja yang telah mengabaikan nilai-nilai, kaidah, norma serta hukum yang berlaku dalam masyarakat menjadi salah satu pemicu maraknya penyalagunaan narkoba di kalangan generasi muda. Tujuan kegiatan pegabdian adalah mensosialisasikan bahaya penyalagunaan narkoba. Metode yang digunakan adalah pengumpulan data melalalui observasi dan wawancara, pelaksanaan sosialisasi dan melakukan monitoring dan evaluasi. Hasil kegiatan pengabdian kepada masyarakat menunjukkan bahwa masyarakat memperoleh pengetahuan dan pemahaman baik dan benar tentang bahaya penyalagunaan narkoba, sehingga dapat mencegah dan menanggulangi penyalagunaan dan peredaran gelap narkoba khususnya di kalangan generasi muda.
\end{abstract}

Kata kunci: sosialisasi, penyalagunaan narkoba

\begin{abstract}
Drug abuse in Indonesia is increasing and the problems caused are also increasingly complex. It is undeniable that drug abuse occurs a lot among teenagers, which has a bad impact both physically, psychologically, socially, economically and so on. The behavior of some teenagers who have ignored the values, rules, norms and laws that apply in society is one of the triggers for the rampant drug abuse among the younger generation. The purpose of community service activities is to socialize the dangers of drug abuse. The method used is data collection through observation and interviews, implementation of socialization and monitoring and evaluation. The results of community service activities show that the community gains knowledge and understanding about the dangers of drug abuse, so that it can prevent drug abuse and circulation, especially among the younger generation.
\end{abstract}

Keywords: socialization, drug abuse

Copyright (c) 2021 Nur Moh Kasim, Sri Nanang Meiske Kamba, Trubus Semiaji

$\triangle$ Corresponding author

Address : Universitas Negeri Gorontalo

ISSN 2721-9224 (Media Cetak)

Email : meiskekamba@gmail.com

ISSN 2721- 9216 (Media Online)

DOI : https://doi.org/10.31004/abdidas.v2i6.465 
1277 Sosialisasi tentang Bahaya Penyalagunaan Narkoba di Kalangan Masyarakat Desa Bualemo - Nur Moh Kasim, Sri Nanang Meiske Kamba, Trubus Semiaji

DOI: https://doi.org/10.31004/abdidas.v2i6.465

\section{PENDAHULUAN}

NAPZA (Narkotoka, Psikotropika dan Zat Adiktif lain) adalah kelompok obat yang berpengaruh pada kerja tubuh, terutama pada otak. Satusisi narkoba merupakan obat atau bahan yang bermanfaat di bidang pengobatan atau pelayanan kesehatan, namun di sisi lain narkoba menimbulkan ketergantungan yang merugikan apabila disalah gunakan atau digunakan tanpa pengendalian dan pengawasan yang ketat. (Sholihah, 2015).

Indonesia darurat narkoba, hal ini dibuktikan dengan angka atau prevalensi penyalahgunaan narkoba dari tahun ketahun terus mengalami peningkatan. Fakta di lapangan menunjukkan sebanyak $50 \%$ penghuni dari Lembaga Pemasyarakatan (LAPAS) di sebabkan oleh kasus narkoba. Berita penyalahgunaan narkoba di kalangan masyarakat menyebar luas baik di media cetak maupun media elektronik (Eleanora, 2011).

$$
\text { Penyalahgunaan narkoba merupakan }
$$
persoalan yang sangat memprihatinkan. Penyebabnya merupakan kompleksitas dari berbagai factor, baik faktor fisik, psikis maupun faktor lingkungan. Penyalahgunaan narkoba memberikan dampak buruk terhadap berbagai aspek kehidupan masyarakat. Secara keseluruhan akibat dari penyalagunaan narkoba tidak hanya bagi pengguna atau pengedar tetapi berakibat pada ganggunan kejiwaan, sosial, ekonomi dan masa depan generasi muda.(Jumaidah, 2017).

Perilaku sebagian generasi muda yang telah mengabaikan nilai-nilai, kaidah, norma serta hukum yang berlaku dalam masyarakat menjadi salah satu pemicu maraknya penyalagunaan narkoba di kalangan generasi muda. (Maudy Pritha Amanda, 2017).

Indonesia telah mengupayakan seperangkat instrumen pengaturan guna untuk mencegah dan menindaklanjuti persoalan penyalahgunaan narkoba di kalangan masyarakat. Bukti dari keseriusan pemerintah Indonesia dalam melakukan pencegahan dan menanggulangi penyalagunaan narkoba telah diwujudkan dengan dikeluarkannya Undang-Undang Nomor 35 Tahun 2009 tentang Narkotika.

Berdasarkan permasalahan diatas, maka pihak Badan Narkotika Nasional Kabupaten Gorontalo Utara bekerjasama dengan LPPM Universitas Negeri Gorontalo memfokuskan melakukan pencegahan penyalagunaan narkoba melalui Program Pengabdian kepada Masyarakat (PkM). Adapun alasan pemilihan lokasi kegiatan PkM ini, dikarenakan Desa Bualemo merupakan lokasi rawan penyalagunaan narkoba yang terletak di pengunungan sehingga membuka peluang bagi orang yang tidak bertaggungjawab untuk melakukan peredaran gelap narkoba di kalangan masyarakat khususya generasi muda.

Tujuan program pengabdian kepada masyarakat ini adalah meningkatkan pengetahuan dan pemahaman masyarakat khususnya generasi muda dalam pencegahan penyalagunaan narkoba.

\section{METODE}

Program pengabdian kepada masyarakat ini objeknya adalah masyarakat khususnya generasi muda Desa Bualemo. Metode dalam menyelesaikan persoalan diatas sebagai berikut:

1. Melakukan observasi dan wawancara yang bertujuan untuk mengidentifikasi lokasi rawan penyalagunaan narkoba di Desa Bualemo yang dilaksanakan mulai tanggal 14-25 September 2021 dengan mengunjugi empat Dusun di Desa Bualemo. Dari hasil observasi dan wawancara yang dilakukan oleh mahasiswa diperoleh informasi bahwa masyarakat kurang memahami dan 
1278 Sosialisasi tentang Bahaya Penyalagunaan Narkoba di Kalangan Masyarakat Desa Bualemo - Nur Moh Kasim, Sri Nanang Meiske Kamba, Trubus Semiaji

DOI: https://doi.org/10.31004/abdidas.v2i6.465

mengetahui bahaya penyalagunaan narkoba.

2. Melakukan sosialisasi yang bertujuan untuk peningkatan pengetahuan dan pemahaman masyarakat tentang bahayanya penyalahgunaan narkoba dikalangan masyarakat Desa Bualemo Kecamatan Kwandang Kabupaten Gorontalo Utara. Kegiatan sosialisasi dihadiri oleh masyarakat, karang taruna, mahasiswa, perangkat desa, dosen dan pihak Badan Narkotika Nasional Kabupaten Gorontalo Utara.

3. Melakukan monitoring dan evaluasi sejauh mana keberhasilan kegiatan PkM yag telah dilaksanakan melalui penyebaran angket dengan menggunakan metode Service Quality (SERVQUAL). Selanjutnya, hasil evaluasi dijadikan sebagai bahan perbaikan apakah hal-hal yang diajarkan mampu diaplikasikan atau tidak dalam masyarakat.

\section{HASIL DAN PEMBAHASAN}

Permasalahan narkoba di Indonesia sudah sangat mengkhawatirkan. Khawatiran ini semakin dipertajam akibat maraknya peredaran narkoba di kalangan generasi muda. Dalam kurun satu dekade terakhir terbukti jumlah pengguna atau pecandu narkotika meningkat secara signifikan. Penyalahgunaan narkoba memberikan dampak buruk bagi kelangsungan hidup si pengguna serta masa depan si pengguna/pengedar tanpa membedakan stara pendidikan dan usia. (Maudy Pritha Amanda, 2017).

Pada tahap awal, tim pengabdian kepada masyarakat melakukan observasi dan wawancara dengan masyarakat di Desa Bualemo yang dilaksanakan pada tanggal 17-23 September 2021. Tujuan dilakukan observasi dan wawancara untuk mengetahui dan mengidentifikasi persoalan yang terjadi di kalangan masyarakat. Observasi dan wawancara dilakukan oleh mahasiswa di empat Dusun Desa Bualmeo Kecamatan Kwandang Kabupaten Gorontalo Utara. Dari hasil observasi dan wawancara diperoleh beberapa faktor penyebab sebagai berikut: (a) kurangnya sosialisasi hukum tentang penyalagunaan narkoba, (b) kurangnya pemahaman masyarakat tentang Undang-Undang Nomor 35 Tahun 2009 tentang Narkotika, (c) rendahnya kesadaran masyarakat terhadap bahayanya penyalagunaan narkoba dilakangan masyarakat.

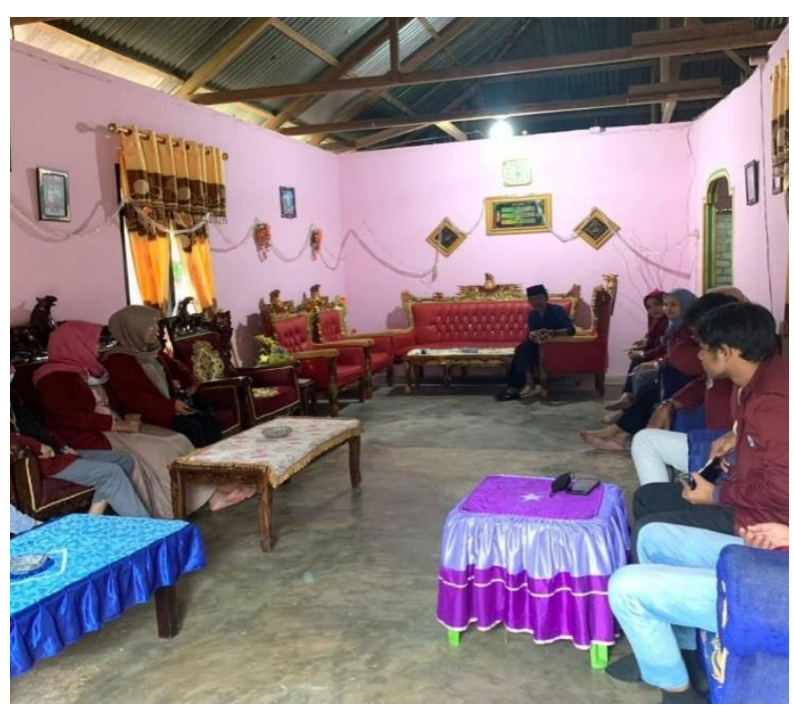

Gambar 1. Wawancara

Kegiatan selanjutnya dilakukan sosialisasi tentang bahaya penyalagunaan narkoba. Kegiatan sosialisasi ini dilaksanakan pada tanggal 9 Oktober 2021 yang dihadiri oleh 30 orang. Pembukaan kegiatan sosialisasi ini dilakukan oleh Sub Koordinator Pencegahan dan Pemberdayaan Masyarakat (P2M) dan dihadiri oleh perwakilan staf Bidang Rehabilitasi. Kegiatan sosialisasi tentang bahayanya penyalagunaan narkoba diberikan oleh Ibu Amanda Luciana S.I.Kom sebagai pemateri sosialisasi. Muatan materi yang diberikan adalah pengertian narkoba, ciri-ciri 
1279 Sosialisasi tentang Bahaya Penyalagunaan Narkoba di Kalangan Masyarakat Desa Bualemo - Nur Moh Kasim, Sri Nanang Meiske Kamba, Trubus Semiaji

DOI: https://doi.org/10.31004/abdidas.v2i6.465

pengguna narkoba dan ancaman hukuman bagi pengedar maupun pengguna narkoba.

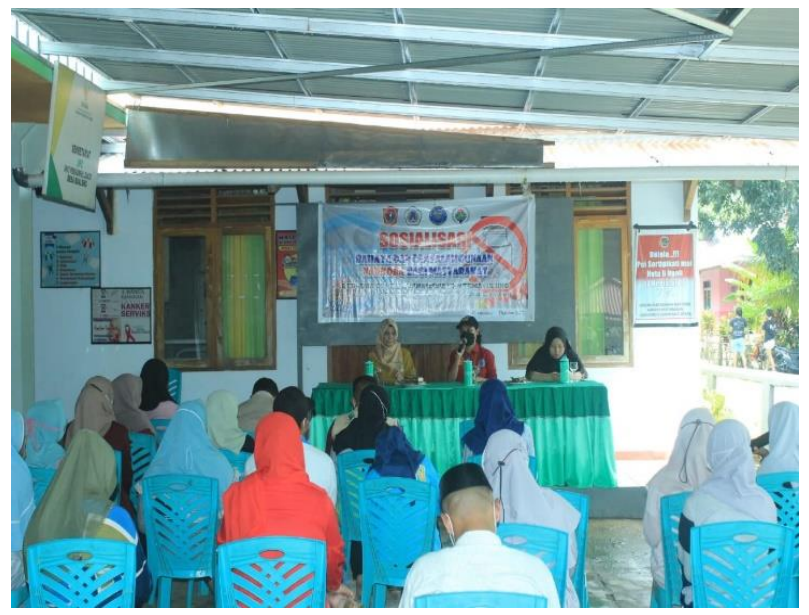

Gambar 2. Sosialisasi

Kegiatan sosialisasi ini bersifat interaktif dengan memberikan edukasi melalui tanya jawab dengan masyarakat sebagai peserta kegiatan sosialisasi. Peserta sosialisasi terlihat antusias mengikuti materi yang disampaikan oleh pemateri. Pada kesempatan ini pula pemateri mengajak masyarakat berperan aktif dalam pencegahan narkoba khususnya dikalangan generasi muda.

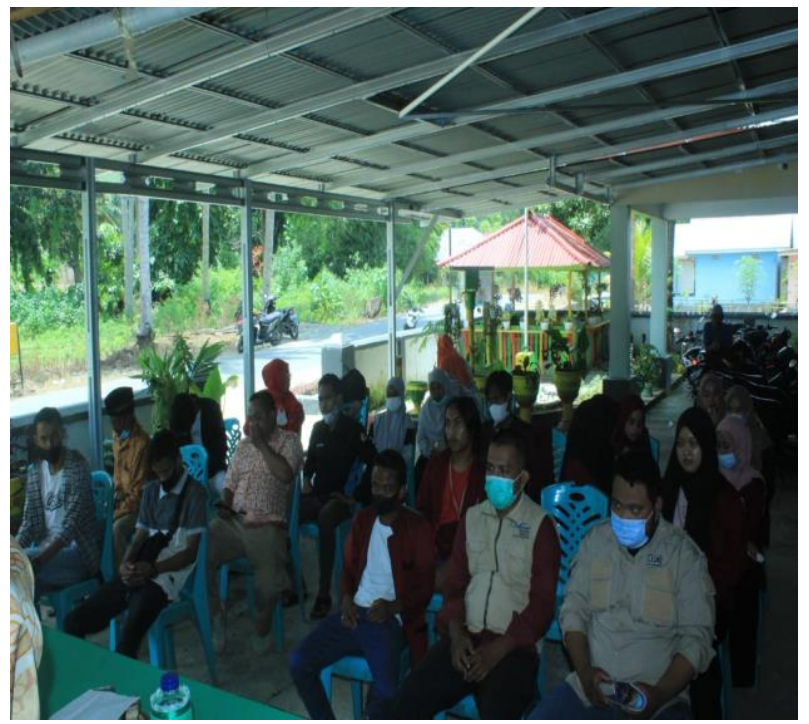

Gambar 3. Peserta Sosialisasi

Keseluruhan rangkaian kegiatan PkM yang dilaksanakan oleh tim dan masyarakat sudah memberikan hasil yang diharapkan. Dampak dari pelaksanaan kegiatan PkM ini adalah masyarakat mendapatkan gambaran tentang bagaimana bahaya, larangan, sanksi serta strategi pencegahanan penyalahgunaan dan peredaran gelap narkoba di kalangan masyarakat khususnya generasi muda. Adapun manfaat dari kegiatan PkM ini menumbuhkan kesadaran hukum sejak dini bagi masyarakat, sehingga perilaku taat hukum akan mendarah daging dan membudaya dalam masyarakat.

\section{SIMPULAN}

Terlaksananya kegiatan pengabdian kepada masyarakat $(\mathrm{PkM})$ dapat di simpulkan bahwa masyarakat di Desa Bualemo Kecamatan Kwandang Kabupaten Gorontalo Utara memperoleh pengetahuan dan pemahaman yang baik dan benar tentang bahaya penyalagunaan narkoba sehingga memberikan manfaat bagi masyarakat. melalui sosialisasi ini dapat mencegah dan menanggulangi penyalagunaan dan peredaran gelap narkoba khususnya di kalangan generasi muda.

\section{UCAPAN TERIMA KASIH}

Terima kasih kepada LPPM UNG, Badan Narkotika Nasional (BNN) Kabupaten Gorontalo Utara, Kepala Desa Bualemo Kecamatan Kwandang KabupatenGorontalo Utara, masyarakat dan karang taruna yang telah membantu dan memfasilitasi sehingga kegiatan sosialisasi ini berjalan dengan lancar. Semoga kegiatan sosialisasi ini menambah pengetahuan dan partisipasi masyarakat khususnya generasi muda dalam mencegah penyalagunaan narkoba di Desa Bualemo.

\section{DAFTAR PUSTAKA}

Eleanora, F. N. 2011. Bahaya Penyalagunaan Narkoba Serta Usaha Pencegahan dan 
1280 Sosialisasi tentang Bahaya Penyalagunaan Narkoba di Kalangan Masyarakat Desa Bualemo - Nur Moh Kasim, Sri Nanang Meiske Kamba, Trubus Semiaji

DOI: https://doi.org/10.31004/abdidas.v2i6.465

Penanggulannya. Jurnal Hukum Vol. XXV, No. 1 , 440.

Jumaidah, R. 2017. Perilaku Pencegahan Penyalagunaan Narkoba Pada Remaja Di Wilaya Kecamatan Sukmajaya, Depok . Jurnal Ilmiah KesehatanVol. 16 No.3, 43.

Maudy Pritha Amanda, S. H. 2017. Penyalagunaan Narkoba di Kalangan Remaja. Jurnal Penelitian dan PPMVol.4 No. 2,340 .

Sholihah, Q. (2015). Efektivitas Program P4GN Terhadap Pencegahan Penyalagunaan NAPZA. Jurnal Kesehatan MasyarakatVol.4 No.2, 154. 